Please do not remove this page

RMIT

UNIVERSITY

\title{
ZnO based thermopower wave sources
}

Walia, Sumeet; Weber, Rodney; Balendhran, Sivacarendran; Yao, David; Abrahamson, Joel T.; Zhuiykov, Serge; Bhaskaran, Madhu

https://researchrepository.rmit.edu.au/esploro/outputs/9921858434301341/filesAndLinks?institution=61RMIT_INST\&index=null

Walia, S., Weber, R., Balendhran, S., Yao, D., Abrahamson, J. T., Zhuiykov, S., Bhaskaran, M., Sriram, S., Strano, M., \& Kalantar Zadeh, K. (2012). ZnO based thermopower wave sources. Chemical Communications, 48(60), 7462-7464. https://doi.org/10.1039/c2cc33146b

Document Version: Accepted Manuscript

Published Version: https://doi.org/10.1039/c2cc33146b

Repository homepage: https://researchrepository.rmit.edu.au

(C) The Royal Society of Chemistry 2012

Downloaded On 2023/04/26 19:38:31 +1000

Please do not remove this page 
Thank you for downloading this document from the RMIT Research Repository.

The RMIT Research Repository is an open access database showcasing the research outputs of RMIT University researchers.

RMIT Research Repository: http://researchbank.rmit.edu.au/

\section{Citation:}

Walia, S, Weber, R, Balendhran, S, Yao, D, Abrahamson, J, Zhuiykov, S, Bhaskaran, M, Sriram, S, Strano, M and Kalantar Zadeh, K 2012, 'ZnO based thermopower wave sources', Chemical Communications, vol. 48, no. 60, pp. 7462-7464.

See this record in the RMIT Research Repository at:

http://researchbank.rmit.edu.au/view/rmit:16412

Version: Accepted Manuscript

Copyright Statement: (C) The Royal Society of Chemistry 2012

Link to Published Version:

http://dx.doi.org/10.1039/c2cc33146b 


\title{
ZnO based thermopower wave sources
}

\author{
Sumeet Walia, ${ }^{* a}$ Rodney Weber ${ }^{b}$ Sivacarendran Balendhran, ${ }^{a}$ David Yao, ${ }^{a}$ Joel. T Abrahamson, ${ }^{c}$ Serge \\ Zhuiykov, ${ }^{d}$ Madhu Bhaskaran, ${ }^{a}$ Sharath Sriram, ${ }^{a}$ Michael S. Strano, ${ }^{c}$ and Kourosh Kalantar-zadeh ${ }^{a}$
}

\author{
Received (in $X X X, X X X)$ Xth $X X X X X X X X X 20 X X$, Accepted Xth XXXXXXXXX 20XX \\ DOI: 10.1039/b000000x
}

\begin{abstract}
Exothermic chemical reactions from nitrocellulose are coupled onto thermoelectric zinc oxide $(\mathrm{ZnO})$ layers to generate self-propagating thermopower waves resulting in highly oscillatory voltage output of the order of $500 \mathrm{mV}$. The ${ }_{10}^{10}$ peak specific power obtained from $\mathrm{ZnO}$ based sources is approximately $0.5 \mathrm{~kW} \mathrm{~kg}^{-1}$.
\end{abstract}

The development of miniaturized power sources with efficient energy storage capabilities is still one of the greatest technological challenges. There are fundamental limits in 15 scaling down the size of rechargeable energy sources to the micro realm and smaller dimensions. Problems such as disruption of ionic flow near electrodes and plasma discharges impede the effective size reduction for sources such as batteries and fuel cells. ${ }^{1,2}$ Additionally, elements such as 20 supercapacitors are incapable of holding charges for a long time, due to their high self-discharge rates. ${ }^{3}$ The development of many fascinating applications such as "cardiac microdefibrillators" and "smart dust" are currently hampered by lack of suitable sized power sources. ${ }^{4}$ Also, micro/nano-sized 25 energy sources could potentially be used for precisely targeting cancer cells by exerting localised, highly directional pulses of energy. ${ }^{5}$ Hence, in order to achieve true miniaturization and the realization of the aforementioned applications, we need to look beyond the conventional 30 methods of energy generation.

New thermopower wave-based energy sources are particularly attractive as they are capable of generating higher specific power (power-to-mass ratio) in comparison to many of the conventional sources such as batteries and fuel cells, 35 especially at small dimensions. ${ }^{6,7}$ Additionally, they are capable of producing alternating currents (AC), which is desirable for practical applications unlike batteries and fuel cells that are only capable of producing direct current (DC). ${ }^{8}$

Chemically driven thermopower waves guided by multi40 walled carbon nanotubes (MWNTs) have been shown to generate specific powers as large as $7 \mathrm{~kW} \mathrm{~kg}^{-1} .^{9}$ In such devices the electrically conductive MWNT core allows the transportation of free electrical carriers that are generated as a result of a large temperature gradient across the device. This 45 temperature gradient is attained as a result of an exothermic reaction of a highly reactive solid fuel covering the MWNTs.

One of the main limitations of the MWNT based thermopower devices is the low voltage and oscillation amplitudes. We have recently demonstrated thermopower 50 wave generation using bismuth telluride $\left(\mathrm{Bi}_{2} \mathrm{Te}_{3}\right)$ and antimony telluride $\left(\mathrm{Sb}_{2} \mathrm{Te}_{3}\right)$ as the core thermoelectric materials. ${ }^{10}$ These devices produced highly oscillatory voltages $(100-150 \mathrm{mV})$ and specific powers of up to $1 \mathrm{~kW} \mathrm{~kg}^{-1}$. In order to make such systems practically suitable, ${ }_{55}$ higher output voltages are desired. In order to achieve this, materials with a high Seebeck coefficient, electrical conductivity and thermal conductivity are required. A high thermal conductivity is essential for sustaining the propagation of the thermopower waves.

${ }_{60}$ Zinc oxide $(\mathrm{ZnO})$, an $\mathrm{N}$-type semiconducting oxide, appears as an outstanding candidate as the core thermoelectric material for thermopower based energy sources. $\mathrm{ZnO}$ exhibits a relatively high Seebeck coefficient (approximately $-360 \mu \mathrm{V} \mathrm{K}^{-1}$ at $85^{\circ} \mathrm{C}$ ) which increases with temperature, a ${ }_{65}$ high electrical conductivity at elevated temperatures of above $300{ }^{\circ} \mathrm{C}\left(\mathrm{ZnO}\right.$ film resistance of $250 \Omega$ at $300{ }^{\circ} \mathrm{C}$ ) hence suitable for operation in thermopower wave sources), high thermal conductivity $\left(15 \mathrm{~W} \mathrm{~m}^{-1} \mathrm{~K}^{-1}\right.$ at $\left.300{ }^{\circ} \mathrm{C}\right)$ and good chemical stability. ${ }^{11}$ The temperature dependance of the ${ }_{70}$ Seebeck coefficient and electrical conductivity will be discussed later in the manuscript.

In this work, we show that $\mathrm{ZnO}$ based thermopower devices are capable of generating significantly larger voltages and oscillation amplitudes than previously reported systems 75 utilising MWNTs, $\mathrm{Bi}_{2} \mathrm{Te}_{3}$ and $\mathrm{Sb}_{2} \mathrm{Te}_{3}$ as the core thermoelectric materials.

The $\mathrm{ZnO}$ films were deposited on alumina $\left(\mathrm{Al}_{2} \mathrm{O}_{3}\right)$ substrates using RF magnetron sputtering (see ESI $\uparrow, \mathrm{S} 1$ ) for details). Previous work carried out on RF sputtered $\mathrm{ZnO}$ films 80 shows that their resistivity can vary up to 8 orders of magnitude depending on the sputtering power and the substrate temperature. ${ }^{12}$ Consequently, in this work we used a high sputtering power $(160 \mathrm{~W})$ and no substrate heating in order to synthesise crystalline and electrically conductive $\mathrm{ZnO}$ 85 thin films $(\sim 1.2 \mu \mathrm{m})$. Nitrocellulose $\left[\mathrm{C}_{6} \mathrm{H}_{8}\left(\mathrm{NO}_{2}\right)_{2} \mathrm{O}_{5}\right]$ was used as the fuel, due to its large enthalpy of reaction $\left(4.75 \times 10^{6} \mathrm{~J} \mathrm{~kg}^{-1}\right) \cdot{ }^{13}$ Sodium azide $\left(\mathrm{NaN}_{3}\right)$ in aqueous solution $\left(50 \mathrm{mg} \mathrm{mL}^{-1}\right)$ was then added to serve as a primary igniter to lower activation energy $\left(40 \mathrm{~kJ} \mathrm{~mol}^{-1}\right.$ for $\mathrm{NaN}_{3}$, 90 compared to $110-150 \mathrm{~kJ} \mathrm{~mol}^{-1}$ for nitrocellulose, (see ESI $\dagger$, $\mathrm{S} 1$ ). A schematic of the fuel/ $\mathrm{ZnO} / \mathrm{Al}_{2} \mathrm{O}_{3}$ is shown in Figure 1. 


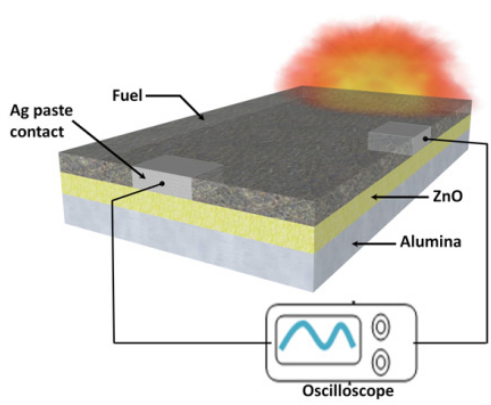

Fig. 1 Schematic of a fuel/ $\mathrm{ZnO} / \mathrm{Al}_{2} \mathrm{O}_{3}$ thermopower wave generation system (not to scale).

Ignition was initiated at one end using a blow torch with a ${ }_{5}$ fine tip resulting in self-propagating reaction waves that travels at a rapid pace to the opposite end. ${ }^{9,10}$ This accelerated reaction wave entrains a simultaneous wave of electrical carriers resulting in an oscillatory voltage output.

The optical photos of the samples before and after the 10 reaction are shown in Figure 2a. A typical thermopower voltage signal obtained across a sample of the fuel/ $\mathrm{ZnO} / \mathrm{Al}_{2} \mathrm{O}_{3}$ system is shown in Figure $2 \mathrm{~b}$. The voltage profile exhibits two distinct regions: an initial phase during the wave propagation and a cooling down phase until the temperature 15 across the $\mathrm{ZnO}$ film reaches equilibrium. The initial reaction phase is a region of rising voltage as the wavefront spreads across the sample until all the combustion fuel is consumed. This is followed by a region of exponential decay. The moving temperature gradient results in voltages with peak

20 magnitudes of up to $500 \mathrm{mV}$ and oscillations with peak-topeak amplitude of up to $400 \mathrm{mV}$. The power obtained from these devices can be as large as $1 \mathrm{~mW}$ (see ESI†, S2\&S3).

We have previously adapted the theory of combustion waves to describe coupled thermal waves in fuel/ $/ \mathrm{Bi}_{2} \mathrm{Te}_{3} / \mathrm{Al}_{2} \mathrm{O}_{3}$ 25 and fuel $/ \mathrm{Sb}_{2} \mathrm{Te}_{3} / \mathrm{Al}_{2} \mathrm{O}_{3}$ systems. ${ }^{10}$ Using the model presented by Mercer et al. and McIntosh et al. we were able to predict the oscillatory behaviour and the propagation velocity of the thermopower waves. ${ }^{14}$ The theoretical analysis concluded that the oscillatory behaviour and wave front velocities strongly 30 depend on the thermal conductivity. A change in thermal conductivity affects the heat loss parameters of the system. It was demonstrated that a higher thermal conductivity enhances the heat transfer through the thermoelectric core, resulting in a proportional increase in combustion velocities. Consequently, ${ }_{35} \mathrm{Sb}_{2} \mathrm{Te}_{3}$ based systems exhibited combustion velocities that were almost 2.5 times faster than the $\mathrm{Bi}_{2} \mathrm{Te}_{3}$ based devices reflecting the difference in the thermal conductivities of the two materials. ${ }^{10 b}$

Hence, based on the aforementioned analysis we expect 40 that a higher thermal conductivity of $\mathrm{ZnO}\left(\sim 15.0 \mathrm{~W} \mathrm{~m}^{-1} \mathrm{~K}^{-1}\right)$ compared to $\mathrm{Bi}_{2} \mathrm{Te}_{3} \quad\left(1.0 \mathrm{~W} \mathrm{~m}^{-1} \mathrm{~K}^{-1}\right)$ and $\mathrm{Sb}_{2} \mathrm{Te}_{3}$ $\left(2.5 \mathrm{~W} \mathrm{~m}^{-1} \mathrm{~K}^{-1}\right)$ would result in a faster wave velocity and larger oscillations. The velocity of the waves in our system was assessed using the duration in which the output voltage 45 exists. We have previously shown that the duration of the voltage signal corresponds to the reaction wave propagation time which enables us to calculate the linear propagation velocity of the thermopower waves. $^{10} \mathrm{~A}$ high thermal conductivity of the $\mathrm{ZnO}$ thermoelectric material provides an
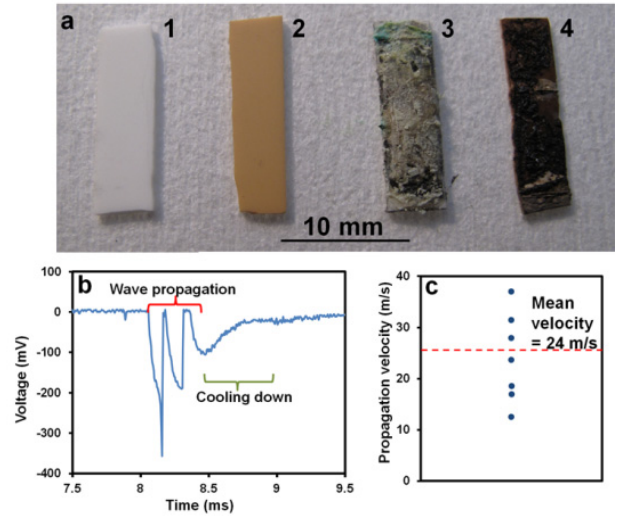

Fig. 2 a) Photo of the $1 . \mathrm{Al}_{2} \mathrm{O}_{3}$ substrate, 2. $\mathrm{ZnO}$ deposited on $\mathrm{Al}_{2} \mathrm{O}_{3}$ substrate, 3. fuel $/ \mathrm{ZnO} / \mathrm{Al}_{2} \mathrm{O}_{3}$ sample and 4. Sample after thermopower wave propagation. b) Oscillatory thermopower voltage signal obtained using the fuel $/ \mathrm{ZnO} / \mathrm{Al}_{2} \mathrm{O}_{3}$ device. c) Reaction propagation velocities for 55 the fuel $/ \mathrm{ZnO} / \mathrm{Al}_{2} \mathrm{O}_{3}$ thermopower systems.

extra path for heat conduction (i.e. the surface of the $\mathrm{ZnO}$ film) in addition to the path provided by the thermally conductive $\mathrm{Al}_{2} \mathrm{O}_{3}$ substrate. As a result, we initially expect the rate of heat conduction for $\mathrm{ZnO}$-based devices to be 60 approximately 15 times faster than $\mathrm{Bi}_{2} \mathrm{Te}_{3}$-based thermopower devices. Propagation velocities for the $\mathrm{ZnO}$ based devices were measured to range between $12-35 \mathrm{~m} \mathrm{~s}^{-1}$ (Figure 2c) which was generally 15-25 times higher than the velocities for $\mathrm{Sb}_{2} \mathrm{Te}_{3}\left(1.2 \mathrm{~m} \mathrm{~s}^{-1}\right)$ and $\mathrm{Bi}_{2} \mathrm{Te}_{3}\left(0.4 \mathrm{~m} \mathrm{~s}^{-1}\right)$ based devices ${ }_{65}$ demonstrated in our previous work. ${ }^{10}$ This difference nicely corresponds to the variation in the thermal conductivities of these materials and is in excellent agreement with theoretical expectations.

We have previously shown that in a thin film thermopower 70 system configuration, incorporating nitrocellulose as the fuel, the reaction temperature remains under $300{ }^{\circ} \mathrm{C} .{ }^{10} \mathrm{As}$ a result, we needed to estimate the Seebeck coefficient and resistance of the $\mathrm{ZnO}$ films within this range.

Kim et al. have shown that the Seebeck coefficient of $\mathrm{ZnO}$ 75 increases with temperature. In their work, it has been demonstrated that the Seebeck coefficient of $\mathrm{ZnO}$ is approximately $-300 \mu \mathrm{V} \mathrm{K}^{-1}$ at $85^{\circ} \mathrm{C} .^{11 a}$ In our measurements the Seebeck coefficient of the $\mathrm{ZnO}$ films was measured to be approximately $-360 \mu \mathrm{V} \mathrm{K}^{-1}$ (see ESI $\uparrow$, S4). At $300{ }^{\circ} \mathrm{C}$ the 80 Seebeck coefficient is expected to be approximately $-500 \mu \mathrm{V} \mathrm{K}^{-1}$ based on linear extrapolation. ${ }^{11 a}$

It has been reported that $\mathrm{ZnO}$ exhibits a negative temperature coefficient of resistance at temperatures up to $350{ }^{\circ} \mathrm{C} .{ }^{15} \mathrm{We}$ measured $\mathrm{ZnO}$ film resistance at temperatures of 85 up to $300^{\circ} \mathrm{C}$ as shown in Figure $3 \mathrm{a}$, which is in close agreement with the value of the temperature coefficient of resistance suggested in the work of Caillaud et al. (approximately $-3.5 \times 10^{-3}{ }^{\circ} \mathrm{C}^{-1}$ ). ${ }^{15 a}$ At $300^{\circ} \mathrm{C}$ the resistance was reduced to approximately $250 \Omega$. This is not an ideal 90 internal impedance for a power source, however it resulted in the maximum current of the order of $2 \mathrm{~mA}$ in our system in a short circuit load condition.

Figure $3 \mathrm{~b}$ illustrates the Raman spectra (indicated as ' 1 ') of the as-grown $\mathrm{ZnO}$ structure. The peaks observed at around ${ }_{95} 436$ and $576 \mathrm{~cm}^{-1}$ correspond to the $\mathrm{E}_{2}$ (high) and the 

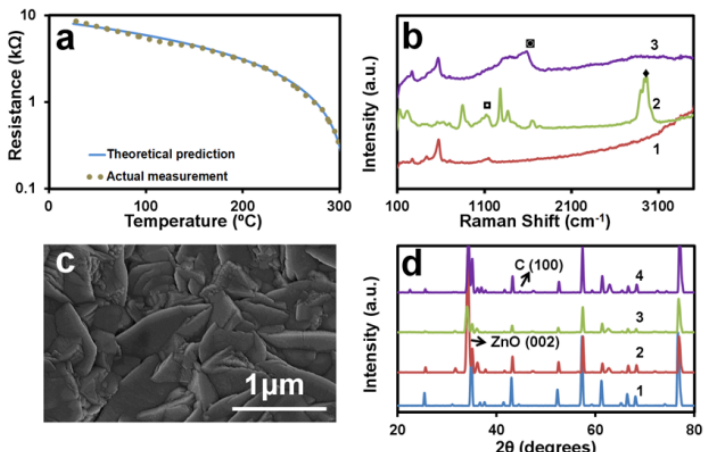

Fig. 3 a) Change of resistance of $\mathrm{ZnO}$ film with temperature. b) Raman spectra of 1. ZnO film, 2. Nitrocellulose coated $\mathrm{ZnO}$ film (a peak denotes strong $\mathrm{NO}_{2}$ bonds, denotes strong $\mathrm{C}-\mathrm{H}$ bonds), 3. After the reaction ( 0 peak denotes carbon). c) SEM micrograph of $\mathrm{ZnO}$ film, d) XRD pattern of 1 . $\mathrm{Al}_{2} \mathrm{O}_{3}$ substrate, 2. $\mathrm{ZnO}$ before thermopower wave propagation, 3. after adding nitrocellulose and 4 . after thermopower wave propagation.

dominant $\mathrm{A}_{1}$ (LO) modes, respectively. The $\mathrm{E}_{2}$ (high) is a characteristic mode of the $\mathrm{ZnO}$ hexagonal wurtzite type 10 lattice. ${ }^{16}$ The Raman peaks after the deposition of nitrocellulose (spectrum ' 2 ' in Figure $3 \mathrm{~b}$ ) shows the presence of strong $\mathrm{C}-\mathrm{H}$ and $\mathrm{NO}_{2}$ bonds. ${ }^{17}$ After the thermopower wave propagation the $\mathrm{C}-\mathrm{H}$ and $\mathrm{NO}_{2}$ bonds disappear, while carbon peaks appear on the Raman spectra (spectrum ' 3 ' in

${ }_{15}$ Figure $3 \mathrm{~b}$ ). The exothermic reaction causes the $\mathrm{C}-\mathrm{H}$ bonds to decompose, while carbon is left behind as the residual product (see ESI $\dagger$, S5).

The SEM image (Figure 3c) shows that the $\mathrm{ZnO}$ film is composed of crystals of varying sizes $(250 \mathrm{~nm}$ to $1 \mu \mathrm{m})$. The 20 roughness of the $\mathrm{ZnO}$ films was determined to be approximately $250 \mathrm{~nm}$ using atomic force microscopy (AFM). (see ESI†,S6). The X-ray diffraction (XRD) pattern Figure 3d reveals that the $\mathrm{ZnO}$ films are highly crystalline with a strong $c$-directional (002) preferred orientation. Addition of 25 nitrocellulose results in an acute reduction in intensity of the $25.3^{\circ} 2 \theta \mathrm{Al}_{2} \mathrm{O}_{3}$ substrate peak. This is because the $25.3^{\circ} 2 \theta$ $\mathrm{Al}_{2} \mathrm{O}_{3}$ substrate peak lies in the same region as the principal XRD reflections for nitrocellulose (ICDD No. 03-0114). A general decrease in diffrraction intensity due to the 30 nitrocellulose coating inhibiting $X$-ray peneration is observed. ${ }^{10 b}$ The XRD pattern following thermopower wave propagation shows strong $\mathrm{ZnO}$ peaks (Figure 3d) verifying that $\mathrm{ZnO}$ remained largely intact at the end of the process.

We have demonstrated that $\mathrm{ZnO}$ is excellent for application 35 as a core material for thermopower waves' based energy sources as it exhibits a high Seebeck coefficient $\left(-360 \mu \mathrm{V} \mathrm{K}^{-1}\right)$, electrical conductivity $(250 \Omega$ resistance at $\left.300{ }^{\circ} \mathrm{C}\right)$, and thermal conductivity $\left(15 \mathrm{~W} \mathrm{~m}^{-1} \mathrm{~K}^{-1}\right)$. $^{11 a}$ The aforementioned properties of $\mathrm{ZnO}$ 40 resulted in a highly oscillatory voltage output of the order of $500 \mathrm{mV}$ and peak current of the order of $2 \mathrm{~mA}$.

We have experimentally investigated the coupling of an exothermic reaction from a solid fuel (combination of nitrocellulose and sodium azide) to $\mathrm{ZnO}$ layers in order to ${ }_{45}$ generate output power at high rates (up to $0.5 \mathrm{~kW} \mathrm{~kg}^{-1}$ ). Additionally, the amplitude of the maximum output voltage was at least $300 \%$ higher than previously reported thermopower wave systems based on MWNTs, $\mathrm{Bi}_{2} \mathrm{Te}_{3}$ and $\mathrm{Sb}_{2} \mathrm{Te}_{3} .{ }^{9,10}$ The efficiency of the $\mathrm{ZnO}$ based devices is still under $0.2 \%$. However, these 50 sources are capable of delivering large energy pulses (up to 0.5 $\mathrm{kW} / \mathrm{kg}$ ) in very short durations (typically in 1.5 to $80 \mathrm{~ms}$ ). Certainly further work is required in order to improve the efficiency. However, by demonstrating the generation of high amplitude alternating voltages (up to $500 \mathrm{mV}$ ), our work shows a 55 significant improvement in the performance of thermopower wave systems, which will potentially allow their application as a new class of micro-power sources.

$\dagger$ Electronic supplementary information (ESI) available: Experimental 60 details and additional supporting results. See DOI:

${ }^{a}$ RMIT University, Functional Materials and Microsystems Research Group, Melbourne, Australia.E-mail: waliasumeet@gmail.com

${ }^{b}$ University of New South Wales at Australian Defence Force Academy,

School of Physical, Environmental and Mathematical Sciences,

${ }_{65}$ Canberra, Australia.

${ }^{c}$ Massachusetts Institute of Technology, Department of Chemical Engineering, Cambridge, USA.

${ }^{d}$ Commonwealth Scientific Industrial Research Organisation (CSIRO),

Material Science and Engineering Division, Melbourne, Australia.

\section{${ }_{70}$ Notes and references}

1 J. W. Long, B. Dunn, D. R. Rolison and H. S. White, Chem. Rev., 2004, 104, 4463.

2 S. Sekido, Solid State Ionics. 1983, 9-10, Part 2, 777.

3 P. Simon and Y. Gogotsi, Nat Mater, 2008, 7, 845.

754 B. W. Cook, S. Lanzisera and K. S. J. Pister, Proc. IEEE, 2006, 94, 1177.

5 S. Kerzenmacher, J. Ducrée, R. Zengerle and F. von Stetten, J. Power Sour., 2008, 182, 1 .

6 N. J. Dudney, J. Mat. Sci. Eng. B, 2005, 116, 245

807 A. Kirubakaran, S. Jain, R. K. Nema, Ren. \& Sust. Ener. Rev., 2009, 13, 2430.

8 A. Khaligh, A. M. Rahimi, Y. J. Lee, J. Cao, A. Emadi, S. D. Andrews, C. Robinson and C. Finnerty, IEEE Trans. Veh. Tech., 2007, 56, 3709 .

859 W. Choi, S. Hong, J. T. Abrahamson, J.-H. Han, C. Song, N. Nair, S. Baik and M. S. Strano, Nat. Mater., 2010, 9, 423; J. T. Abrahamson, W. Choi, N. S. Schonenbach, J. Park, J-H. Han, M. P. Walsh, K. Kalantar-zadeh and M. S. Strano, ACS Nano, 2011, 5, 367; J. T. Abrahamson, C. Song, J. H. Hu, J. M. Forman, S. G. Mahajan, N. Nair, W. Choi, E. J. Lee and M. S. Strano, Chem. Mat, 2011, 23, 4557.

10 (a) S. Walia, R. Weber, K. Latham, P. Petersen, J. T. Abrahamson, M. S. Strano and K. Kalantar-zadeh, Adv. Funct. Mat., 2011, 21, 2072; (b) S. Walia, R. Weber, S. Sriram, M. Bhaskaran, K. Latham, S. Zhuiykov and K. Kalantar-zadeh, Ener. Env. Sci., 2011, 4, 3558.

11 (a) K. H. Kim, S. H. Shim, K. B. Shim, K. Niihara and J. Hojo, J. Amer. Cer. Soc., 2005, 88, 628; (b) P. Jood, R. J. Mehta, Y. L. Zhang, G. Peleckis, X. L. Wang, R. W. Siegel, T. Borca-Tasciuc, S. X. Dou and G. Ramanath, Nano Lett., 2011, 11, 4337.

10012 S. J. Lim, S. Kwon and H. Kim, Thin Solid Films, 2008, 516, 1523; M. K. Jayaraj, A. Antony and M. Ramachandran, Bull.Mat. Sci., 2002, 25, 227; M. A. Martínez, J. Herrero and M. T. Gutiérrez, Sol. Ener. Mater. Sol. Cells, 1994, 31, 489.

13 E. Lemieux and R. E. Prud'Homme, Thermochimica Acta, 1985, 89, 11.

14 G. N. Mercer, R. O. Weber and H. S. Sidhu, Proc. Royal Soc. A, 1998, 454, 2015; A. C. McIntosh, R. O. Weber and G. N. Mercer, Anz. Jour., 2004, 46, 1.

15 (a) F. Caillaud, A. Smith and J.-F. Baumard, J. Eur. Ceram. Soc., 1991, 7, 379; (b) N. H. Al-Hardan, M. J. Abdullah and A. A. Aziz, Inter. Jour. Hydr. Ener., 2010, 35, 4428.

16 U. Ozgur, Y. I. Alivov, C. Liu, A. Teke, M. A. Reshchikov, S. Dogan, V. Avrutin, S. J. Cho and H. Morkoc, J. App. Phys., 2005, 98, 041301 .

11517 D. S. Moore and S. D. McGrane, J. Mol. Str., 2003, 661, 561. 